Gambaran Kadar SGPT pada Pasien Tuberculosis Multidrug Resistant (TB-MDR)

\title{
Profile of SGPT Levels in Multidrug Resistant Tuberculosis Patients (MDR-TB)
}

\author{
MEISIKA DAMAYANTI \\ SURATI
}

\author{
Jurusan Analis Kesehatan Poltekkes Kemenkes Semarang \\ Jl. Wolter Monginsidi Pedurungan Tengah Semarang \\ Email:meisikad@gmail.com
}

\begin{abstract}
Abstrak
Multidrug Resistant Tuberculosis (TB-MDR) akhir-akhir ini menjadi ancaman kesehatan di Indonesia. Tatalaksana klinis MDR TB lebih rumit bila dibandingkan dengan TB biasa. Hepatotoksik atau biasa disebut dengan Anti-Tuberculosis Drug-induced Hepatotoxicity (ATDH) adalah efek serius dari OAT yang banyak terjadi. Parameter dasar untuk mendiagnosa atau follow up adanya gangguan fungsi hati adalah dengan pemeriksaan SGPT. Tujuan Penelitian ini untuk mengetahui gambaran kadar SGPT pada pada pasien TB-MDR. Penelitian ini merupakan penelitian observasional (non-eksperimental) dengan kriteria penelitian deskriptif dengan pendekatan cross sectional yang dilakukan terhadap 7 pasien TB-MDR di Puskesmas Kendal I, Puskesmas Kaliwungu, dan Puskesmas Kaliwungu Selatan dengan teknik total sampling. Hasil penelitian didapatkan kadar SGPT pada 7 pasien TB-MDR terdapat 7 responden penelitian (100\%) memiliki kadar SGPT normal dengan kadar terendah yaitu 2,17 U/L dan kadar tertinggi yaitu 37,75 U/L dan rata-rata kadar SGPT yaitu 18,01 U/L. TB banyak menyerang kelompok usia 56-65 tahun (57\%). Laki-laki (57\%) merupakan pasien yang banyak terjangkit TB. Waktu konsumsi OAT terbanyak di fase lanjutan $(100 \%)$. Diabetes adalah penyakit yang sering menyertai pasien TB. Simpulan dari penelitian ini adalah dari 7 sujek penelitian yaitu pada pasien TB-MDR memilki kadar SGPT yang masuk dalam rentang normal.
\end{abstract}

Kata Kunci : TB-MDR ; Kadar SGPT

\begin{abstract}
Multidrug Resistant Tuberculosis (MDR-TB) has recently become a health threat in Indonesia. The clinical management of MDR TB is more complicated than that of ordinary TB. Hepatotoxicity or commonly known as Anti-Tuberculosis Drug-induced Hepatotoxicity (ATDH) is a serious effect of OAT that often occurs. The basic parameter for diagnosing or following up the presence of impaired liver function is the SGPT examination. The purpose of this study was to describe the level of SGPT in MDR-TB patients. This study is an observational (non-experimental) study with descriptive research criteria with a cross sectional approach which was conducted on 7 MDR-TB patients at Kendal I Health Center, Kaliwungu Health Center, and South Kaliwungu Health Center with total sampling technique. The results of the study: obtained SGPT levels in 7 patients with MDR-TB there were 7 research respondents (100\%) had normal SGPT levels with the lowest level of 2.17 $U / L$ and the highest level of $37.75 \mathrm{U} / \mathrm{L}$ and the average level of SGPT ie 18.01 U/L. TB mostly attacks the age group of 56-65 years (57\%). Males (57\%) were the patients with the most TB cases. The most OAT consumption time was in the continuation phase (100\%). Diabetes is a disease that often accompanies TB patients. The conclusion of this study is that from 7 research subjects, MDR-TB patients had SGPT levels that were in the normal range.
\end{abstract}




\section{Keywords: $M D R-T B$; SGPT levels}

\section{Pendahuluan}

Tuberkulosis paru merupakan salah satu penyakit saluran pernapasan bagian bawah yang disebabkan oleh bacillus Mycobacterium tuberculosis, yang menyebar ketika orang yang menderita penyakit TBC mengeluarkan bakteri ke udara; misalnya dengan batuk. (WHO, 2019).

Tuberculosis (TB) masuk dalam 10 besar pemicu kematian teratas di dunia dan menjadi pemicu utama kematian dari suatu patogen infeksius. Penyakit TB dapat mempengaruhi paru-paru (TB paru) dan mempengaruhi organ lain (TB luar paru). Secara global, pada tahun 2019 diperkirakan ada 10,0 juta (kisaran 8,9-11,0 juta) orang terinfeksi TB, akhir-akhir ini angka tersebut sudah menurun walau sangat lambat. Tidak hanya tuberkulosis biasa, Multidrug Resistant Tuberculosis (TB-MDR) akhir-akhir ini menjadi momok di dunia kesehatan Indonesia. Saat basil Mycobacterium tuberculosis tidak terbunuh oleh golongan Obat Anti Tuberkulosis (OAT) kategori I seperti isoniazid dan rifampisin, disertai atau tidak disertai resistensi oleh OAT kategori I yang lain maka akan terjadi tuberkulosis resisten ganda. (Saputri \& Munthe, 2020)

Tatalaksana kasus MDR TB sering dikaitkan dengan kejadian efek samping dari ringan hingga berat. Obat Anti Tuberkulosis (OAT) dapat menimbulkan efek samping yang berpengaruh pada kulit, hati,syaraf, serta menimbulkan kelainan pada lambung dan usus. Hepatotoksik dari OAT atau biasa disebut dengan Anti-Tuberculosis Drug-induced Hepatotoxicity (ATDH) adalah efek serius dari OAT yang banyak terjadi. Contoh OAT yang sering menimbulkan efek samping yaitu rifampisin, isoniazid, dan pirazinamid (Kalma, 2016). Tanda terjadinya Anti-Tuberculosis Drug-induced Hepatotoxicity (ATDH) dapat diketahui berdasarkan kadar enzim transaminase yaitu SGOT dan SGPT. Peningkatan enzim hati tersebut mengindikasikan tingkat kerusakan sel-sel hati atau radang pada jaringan hati. Tingginya tingkat kerusakan sel-sel hati, akan berdampak pada tingginya enzim transaminase (Raharjo et al., 2019).

Pemeriksaan SGPT adalah indikator yang lebih sensitif terhadap kerusakan hati dibandingkan SGOT. Hal ini dikarenakan enzim SGPT sumber utamanya di hati. Selain itu kadar SGPT serum meningkat lebih khas dari pada SGOT pada kasus nekrosis hati dan hepatitis akut, sehingga jika dilakukan pemeriksaan terhadap serum seseorang yang mengalami kerusakan hati akibat Obat AntiTuberculosis (OAT) akan lebih efektif menggunakan pemeriksaan SGPT. (Sri, Rahayu \& Sukeksi, 2017)

Menurut latar belakang tersebut, peneliti telah melakukan penelitian tentang gambaran kadar SGPT pada pasien Tuberculosis Multidrug Resistant (TB-MDR).

\section{Metode}

Jenis penelitian ini adalah penelitian kuantitatif dengan jenis penelitian observasional (non-eksperimental) dengan kriteria penelitian deskriptif dan pendekatan cross sectional untuk mengetahui gambaran kadar SGPT pada pada pasien Tuberculosis Multidrug Resistant (TB-MDR) periode Maret - April 2021. Menggunakan teknik total sampling. Sampel dalam penelitian ini adalah pasien Tuberculosis Multidrug Resistant (TB-MDR) yang memenuhi kriteria inklusi sebagai berikut :

1) Subjek merupakan penderita TB-MDR

2) Bersedia menjadi subjek penelitian dan menanadatangani inform consent Kriteria Eksklusi :

1) Subjek penderita TB ekstra paru atau TB-MDR ekstra paru

Data yang diperoleh dalam bentuk data primer yaitu hasil dari pemeriksaan kadar SGPT dari pasien Tuberculosis Multidrug Resistant (TB-MDR) yang kemudian akan diolah sesuai 
kriteria umur, jenis kelamin, lama pengobatan dan penyakit penyerta dari pasien Tuberculosis Multidrug Resistant (TB-MDR). Data tersebut diolah dan disajikan dalam bentuk tabel dan dianalisis secara deskriptif.

\section{Hasil dan Pembahasan}

Penelitian ini dilakukan dengan memeriksa kadar SGPT pada pasien TB-MDR (Tuberculosis Multidrug Resistant) di Puskesmas Kabupaten Kendal dengan jumlah subjek penelitian sebanyak 7 orang. Sampel yang digunakan untuk pemeriksaan kadar SGPT adalah serum yang sebelumnya dilakukan pengambilan darah vena sebanyak $3 \mathrm{cc}$ dan kemudian sampel dikirimkan ke Balai Laboratorium Kesehatan dan PAK Jawa Tengah untuk diperiksa kadar SGPT menggunakan metode Kinetik UV atas rekomendasi IFCC (International Federation of Clinical Chemistry) dengan alat biokimia analyzer sehingga didapatkan kadar SGPT dari sampel serum dengan satuan U/L. Nilai rujukan untuk kadar SGPT adalah $<50$ $\mathrm{U} / \mathrm{L}$.

Tabel 1 Hasil Kadar SGPT Pada Pasien TB-MDR

\begin{tabular}{ccc}
\hline No & Kode & $\begin{array}{c}\text { Hasil } \\
\text { (U/L) }\end{array}$ \\
\hline 1 & RSD & 11,33 \\
2 & BSR & 37,75 \\
3 & AGW & 13,25 \\
4 & ASP & 37,34 \\
5 & CHO & 2,17 \\
6 & SMT & 13,78 \\
7 & RDG & 10,47 \\
\hline Kadar terendah & $\mathbf{2 , 1 7}$ \\
\hline Kadar tertinggi & $\mathbf{3 7 , 7 5}$ \\
\hline \multicolumn{3}{c}{ Rata-rata } \\
\hline
\end{tabular}

Berdasarkan tabel 1 menunjukkan bahwa hasil pemeriksaan kadar SGPT yang dilakukan pada 7 pasien TB-MDR (100\%) memiliki kadar SGPT normal dengan kadar terendah yaitu 2,17 U/L dan kadar tertinggi yaitu 37,75 U/L dan rata-rata kadar SGPT pada 7 pasien TB-MDR yaitu 18,01 U/L.

Tabel 2 Kategori Kadar SGPT Pada Pasien TB-MDR

\begin{tabular}{ccccc}
\hline \multirow{2}{*}{ No } & Kadar SGPT & \multicolumn{2}{c}{ Frekuensi } & \multirow{2}{*}{ Kategori } \\
\cline { 3 - 4 } & $(\mathrm{U} / \mathrm{L})$ & $\mathrm{F}$ & $\%$ & \\
\hline 1 & $<50$ & 7 & 100 & Normal \\
\hline 2 & $>50$ & 0 & 0 & Diatas normal \\
\hline
\end{tabular}

Tabel 2 diartikan bila hasil pemeriksaan kadar SGPT yang didapat adalah $<50 \mathrm{U} / \mathrm{L}$ dikategorikan sebagai kadar SGPT normal dan bila kadar SGPT $>50 \mathrm{U} / \mathrm{L}$ dikategorikan sebagai kadar SGPT diatas normal. Berdasarkan penelitian yang dilakukan pada 7 pasien TB-MDR terdapat 7 responden penelitian (100\%) memiliki kadar SGPT normal dan $0(0 \%)$ responden penelitian dengan kadar SGPT tinggi. 
Tabel 3 Distribusi Frekuensi Kadar SGPT Responden Berdasarkan Usia

\begin{tabular}{ccccccc}
\hline \multirow{2}{*}{ Kelompok Usia } & \multicolumn{4}{c}{ Kadar SGPT } & \multirow{2}{*}{ Total } \\
\cline { 2 - 5 } & \multicolumn{2}{c}{ Normal } & \multicolumn{2}{c}{$\begin{array}{c}\text { Di atas } \\
\text { normal }\end{array}$} & & \\
\cline { 2 - 5 } & $\mathbf{f}$ & $\mathbf{\%}$ & $\mathbf{f}$ & $\mathbf{\%}$ & $\mathbf{F}$ & $\mathbf{\%}$ \\
\hline $\begin{array}{c}\text { Dewasa Akhir (36-45 } \\
\text { tahun) }\end{array}$ & 1 & 100 & 0 & 0 & 1 & 100 \\
\hline $\begin{array}{c}\text { Lansia Awal (46-55 tahun) } \\
\text { Lansia Akhir (56-65 } \\
\text { tahun) }\end{array}$ & 2 & 100 & 0 & 0 & 2 & 100 \\
\hline
\end{tabular}

Berdasarkan tabel 3 menunjukkan bahwa pada kelompok usia dewasa akhir menunjukkan kadar SGPT normal pada 1 orang (100\%) dan tidak ada yang nilainya diatas normal. Kelompok usia lansia awal kadar SGPT normal berjumlah 2 orang $(100 \%)$ dan tidak ada yang nilainya diatas normal. Kadar SGPT pada kelompok usia lansia akhir berjumlah 4 orang $(100 \%)$ dan tidak ada yang diatas normal.

Tabel 4 Distribusi Frekuensi Kadar SGPT Responden Berdasarkan Jenis Kelamin

\begin{tabular}{crrrrrrr}
\hline & \multicolumn{3}{c}{ Kadar } & \multicolumn{2}{c}{ SGPT } & \multirow{2}{*}{ Total } \\
\cline { 2 - 5 } Jenis Kelamin & \multicolumn{2}{c}{ Normal } & \multicolumn{2}{c}{ Tinggi } & & \\
\cline { 2 - 6 } & f & $\%$ & F & $\%$ & F & $\%$ \\
\hline Laki-laki & 4 & 100 & 0 & 0 & 4 & 100 \\
Perempuan & 3 & 100 & 0 & 0 & 3 & 100 \\
\hline
\end{tabular}

Berdasarkan tabel 4 menunjukkan bahwa pada laki-laki kadar SGPT normal berjumlah 4 orang $(100 \%)$ dan kadar SGPT di atas normal berjumlah 0 orang $(0 \%)$. Sedangkan pada perempuan kadar SGPT normal berjumlah 3 orang (100\%) dan kadar SGPT di atas normal berjumlah 0 orang $(0 \%)$.

Tabel 5 Distribusi Kadar SGPT Responden Berdasarkan Lama Pengobatan

\begin{tabular}{cccccccc}
\hline \multirow{2}{*}{ Lama Pengobatan } & \multicolumn{3}{c}{ Kadar SGPT } & \multirow{2}{*}{ Total } \\
\cline { 2 - 6 } & \multicolumn{2}{c}{ Normal } & \multicolumn{2}{c}{$\begin{array}{c}\text { Di atas } \\
\text { normal }\end{array}$} & & \\
\cline { 2 - 6 } & $\mathbf{f}$ & $\mathbf{\%}$ & $\mathbf{F}$ & $\mathbf{\%}$ & $\mathbf{F}$ & $\mathbf{\%}$ \\
\hline $\begin{array}{c}\text { Tahap Awal } \\
(0-4 \text { bulan })\end{array}$ & 0 & 0 & 0 & 0 & 0 & 0 \\
$\begin{array}{c}\text { Tahap Lanjutan } \\
(4-18 \text { bulan })\end{array}$ & 7 & 100 & 0 & 0 & 7 & 100 \\
\hline
\end{tabular}

Berdasarkan tabel 5 menunjukkan bahwa 7 responden (100\%) termasuk pada kelompok lama pengobatan tahap lanjutan. Kelompok pengobatan tahap lanjutan dengan kadar SGPT normal berjumlah 7 orang $(100 \%)$ dan kadar SGPT di atas normal berjumlah 0 orang $(0 \%)$. 
Tabel 6 Distribusi Kadar SGPT Responden Berdasarkan Penyakit Penyerta

\begin{tabular}{ccccccc}
\hline \multirow{3}{*}{ Penyakit penyerta } & \multicolumn{4}{c}{ Kadar SGPT } & \multirow{2}{*}{ Total } \\
\cline { 2 - 6 } & \multicolumn{2}{c}{ Normal } & \multicolumn{2}{c}{$\begin{array}{c}\text { Di atas } \\
\text { normal }\end{array}$} & & \\
\cline { 2 - 6 } & f & $\mathbf{\%}$ & $\mathbf{f}$ & $\mathbf{\%}$ & F & $\mathbf{\%}$ \\
\hline Diabetes Melitus & 4 & 100 & 0 & 0 & 0 & 0 \\
Tidak ada & 3 & 100 & 0 & 0 & 7 & 100 \\
\hline
\end{tabular}

Berdasarkan tabel 6 menunjukkan bahwa 4 responden (100\%) yang memiliki penyakit diabetes melitus memiliki kadar SGPT normal. Responden tanpa penyakit penyerta terdapat 3 responden (100\%) dengan kadar SGPT yang normal.

Penelitian ini menggambarkan kadar SGPT pada pasien Tuberculosis Multi Drug Resistant (TB-MDR) di tiga puskesmas dengan prevalensi kasus tertinggi di Kabupaten Kendal. Hasil pemeriksaan kadar SGPT pada 7 responden penelitian (100\%) menunjukkan seluruh responden mempunyai kadar SGPT yang normal. Berdasarkan penelitian yang dilakukan, MDR-TB banyak diderita oleh kategori usia lansia akhir (56-65 tahun) berjumlah 4 pasien. Semua lapisan usia dapat terjangkit penyakit TBC. Usia berpengaruh dalam angka kejadian penyakit tuberkulosis. Tuberkulosis paru sering menyerang kategori usia produktif yaitu usia 15-50 tahun. Seseorang yang memungkinkan untuk lebih mudah terpapar dan tertular dari penderita Tuberkulosis biasanya disebabkan karena tingkat aktivitas dan produktivitasnya yang tinggi.

Hal ini mendukung penelitian yang dilakukan oleh Indriani (2020) yang menunjukkan bahwa, pasien tuberkulosis memiliki kisaran usia 19-66 tahun, dengan sebaran usia responden paling banyak dikelompok usia lansia akhir (56-65 tahun) berjumlah 3 responden (30\%). Lansia juga rentan terkena tuberkulosis karena seiring dengan bertambahnya usia, kekebalan tubuh akan menurun dan seluruh fungsi organ mengalami penurunan sehingga mudah terserang penyakit, termasuk penyakit TB Paru (Sobari, 2019). Pada penelitian ini seluruh responden penelitian (100\%) dengan kelompok usia remaja akhir, dewasa awal dan dewasa akhir menunjukkan kadar SGPT yang normal, hal ini mungkin disebabkan oleh daya tahan tubuh yang kuat dan pola hidup yang sehat.

Peningkatan kadar SGPT dalam darah dipengaruhi oleh jenis kelamin. Berdasarkan penelitian yang dilakukan, diketahui 4 responden laki-laki (57\%) dan 3 reponden perempuan (43\%) memiliki kadar SGPT yang normal. Penelitian Yulvia (2014) menyebutkan tuberkulosis mudah menyerang laki-laki, hal ini terkait sistem imun laki-laki yang lebih rendah dibanding perempuan serta kebisaan laki-laki yang sering beraktivitas di luar rumah lebih berisiko terpapar bakteri Mycobacterium tuberculosis dari orang lain. Pada penelitian ini seluruh responden penelitian (100\%) baik laki-laki maupun perempuan menunjukkan kadar SGPT yang normal, daya tahan tubuh yang kuat dan pola hidup sehat mungkin jadi penyebabnya. Hasil dari penelitian (Rasyid et al., 2020) menggunakan responden penelitian yang dibedakan sesuai jenis kelamin dan usia menunjukkan bahwa $20 \%$ penderita TB memiliki peningkatan kadar SGPT dan SGOT dengan SGOT rata-rata adalah $51 \mathrm{U} / \mathrm{L}$ dan SGPT adalah $42.5 \mathrm{U} / \mathrm{L}$, peningkatan level SGOT dan SGPT terjadi pada pasien yang mengkonsumsi OAT 1-2 bulan. Hal ini karena pada jenis kelamin laki-laki peningkatan SGPT lebih tinggi dan semakin tua usia maka kemampuan organ hati akan semakin berkurang

Lama pengobatan dapat mempengaruhi kadar SGPT. Berdasarkan penelitian yang dilakukan, diketahui bahwa 7 responden (100\%) termasuk pada kelompok lama pengobatan tahap lanjutan (4-18bulan) dan memiliki kadar SGPT yang normal. Hasil kadar SGPT pada penelitian ini mendukung penelitian yang dilakukan oleh Anisa (2015) sebanyak 3,1 \% responden kadar SGPT mengalami peningkatan dan sebanyak 96,9\% responden kadar SGPTnya normal setelah 2 bulan pengobatan fase awal. 
Dalam keadaan akut SGPT mudah dilepaskan dari sel hati ke dalam darah, yang memungkinkan kadar SGPT akan normal kembali seperti tidak terjadi peningkatan kadar dalam jangka waktu 6 bulan. Selain itu Obat Anti Tuberkulosis yang dikonsumsi secara teratur dan dikombinasikan dengan vitamin dapat meningkatkan nafsu makan. Hepatoksisitas terjadi tergantung dosis pada tiap individu, sehingga tidak semua individu mengalami hepatotoksisitas. Banyak penderita TB yang mampu menyelesaikan pengobatan tanpa efek samping, tetapi ada beberapa yang mengalami efek samping maka dari itu perlu dilakukan pemantauan terhadap efek samping. (Nurrizqi, 2017)

Berdasarkan penelitian yang dilakukan, terdapat 4 responden yang menderita penyakit diabetes melitus dan 3 reponden yang tidak memiliki riwayat penyakit selain TB memiliki kadar SGPT yang normal. Menurut Leon et. al (2004), salah satu faktor yang dapat meningkatakan resiko tuberkulosis adalah penyakit diabetes. Pada DM aktivitas sel fagosit akan menurun karena terjadi hiperglikemia yang dapat menyebabkan mikroorganisme dalam leukosit terbunuh. Pada DM terjadi hiperglikemia yang dapat menyebabkan menurunnya aktivitas sel fagosit untuk membunuh mikroorganisme dalam leukosit

Faktor-faktor yang mengakibatkan hasil kadar SGPT normal adalah penundaan pemeriksaan karena perbedaan lokasi pemeriksaan dengan pengambilan sampel. Pada daerah terpencil banyak fasilitas kesehatan yang kurang memadai sehingga sampel pasien dari puskesmas harus dikirim ke laboratorium yang fasilitasnya komplit dan membutuhkan waktu yang lama. Sehingga penanganan sampel harus agar sampel tetap stabil. Menurut (Rizky et al., 2019) kadar SGPT yang dilakukan penundaan dalam pemeriksaannya akan mengalami penurunan secara signifikan. SGPT juga merupakan enzim yang bersifat termolabil atau tidak stabil terhadap perubahan suhu.

Normalnya kadar SGPT tidak selalu menunjukkan bahwa seseorang tidak menderita kelainan hati. Sebab, pada kasus penyakit hati menahun (kronis) contohnya pada kasus hepatitis B ata hepatitis C kronik sering ditemukan kadar enzim SGPT yang normal atau hanya sedikit meningkat. Akan terjadi peningkatan yang pesat pada enzim hati saat sel-sel hati mengalami kerusakan, secara perlahan sel hati akan mengalami kerusakan pada infeksi hati kronik, yang menyebabkan SGPT tidak naik secara signifikan bahkan terlihat normal. Maka dari itu diperlukan beberapa pemeriksaan lain yang memperkuat diagnosa adanya kelainan hati.

\section{Simpulan dan Saran}

\section{Simpulan}

Seluruh subjek penelitian yang terdiri atas 4 laki-laki (57\%) dan 3 perempuan (43\%), didominasi oleh pasien berusia $>50$ tahun dengan penyakit Diabetes mellitus, dan telah mengkonsumsi OAT tahap lanjutan memiliki kadar SGPT yang normal dengan kadar tertinggi yaitu 37,75 U/L, kadar terendah yaitu 2,17U/L dan rata-rata kadar SGPT yaitu 18,01 $\mathrm{U} / \mathrm{L}$.

Kadar SGPT pada pasien Tuberculosis Multidrug Resistant (TB-MDR) di Puskesmas Kabupaten Kendal menunjukkan hasil pemeriksaan kadar SGPT dalam rentang normal yang berarti tidak menandakan adanya kerusakan hati akibat konsumsi OAT selama pengobatan.

\section{Saran}

Bagi peneliti selanjutnya dapat dilakukan penelitian yang serupa dengan variabel-variabel berbeda yang belum dibahas dalam penelitian ini seperti pengaruh terhadap riwayat penyakit lain, kepatuhan minum obat, dan riwayat pengobatan.

\section{Daftar Pustaka}

Chairini, S., \& Widodo, W. (2020). Profile of SGOT and SGPT levels in Patients with Pulmonary Tuberculosis. Jaringan Laboratorium Medis, 2(1), 18-21. 
Kalma. (2016). Studi Hasil Pemeriksaan Serum Glutamic Oxalacetic Transaminase Dan Serum Glutamic Phyruvic Transaminase Pada Penderita Tuberkulosis Paru Sebelum Dan Setelah Satu Bulan Mengkonsumsi Obat Anti Tuberkulosis. VII(2), 7-18.

Nurrizqi, T. M. (2017). Pemeriksaan Kadar SGOT dan SGPT pada Penderita Tuberkulosis Akhir Fase Intensif 60.

Raharjo, W., Lestari, R. H., dan Uwan, W. B. (2019). Gambaran Kadar Enzim Transaminase Pada Pasien Tuberkulosis Yang Mendapat Terapi Obat Anti Tuberkulosis Di Unit Pengobatan Penyakit Paru-Paru Provinsi Kalimantan Barat. Jurnal Mahasiswa PSPD FK Universitas Tanjungpura, Vol 5, No, 2-11.

Rasyid, S. A., Armayani, Yuniati, and Lio, T. M. P. (2020). Analysis of Serum Glutamic Pyruvic Transaminase and Serum Glutamic Oxaloacetic Transaminase Levels in Tuberculosis Patient Who are Undergoing Oat Treatment in Kendari City General Hospital, Kota Kendari Indonesia. 12, 75-77. https://doi.org/10.4081/idr.2020

Rizky, V., Wulan, W. S., Kesehatan, J. A., dan Surabaya, P. K. (2019). Vol 8 No . 2 Desember 2019 Issn : 2320 - 3635 Issn : 2320 - 3635. Pengaruh Waktu Penanganan Pemeriksaan Terhadap Kadar Sgpt Pada Serum dan Plasma Edta, 8(2), 777-781.

Saputri, I. N., dan Munthe, E. L. (2020). Tuberkulosis Resisten Ganda (TB-MDR) dan Implementasi Upaya Pengendalian di Kabupaten Ketapang. Jurnal Respirologi Indonesia, 40(1).

Sri, Rahayu \& Sukeksi, A. (2017). Hubungan Kadar SGOT-SGPT Pada Pasien TB Pengobatan Fase Awal Di Puskesmas Pati. Repository Unimus.

Sumiati, D., \& Budiharjo, T. (2019). BTA Suspect Findings Before and After Knocking on the Doors Program by Cadre Based on Quality of Sputum Samples. Jaringan Laboratorium Medis, 1(1), 34-37.

WHO. (2019). WHO TB Report. WHO Library Cataloguing-in-Publication Data World, 7.

Winadiatri, H. (n.d.). Metabolisme Obat Pada Penyakit Kardiovaskuler Halia Winadiatri. 20, $1-4$. 